\title{
Sosialisasi Penangkalan Berita Hoax PKK Kelurahan Karang Besuki Kecamatan Sukun Kota Malang
}

\author{
Hudriyah Mundzir*1 ${ }^{* 1}$ Khrisna Hadiwinata ${ }^{2}$, Shohib Muslim ${ }^{3}$, Sri Hudiarini ${ }^{4}$, Moh. Abdullah Anshori ${ }^{5}$ \\ 1,2,3,4,5 Politeknik Negeri Malang \\ e-mail: *1hudriyah.mundzir@polinema.co.id
}

\begin{abstract}
Abstrak
Permasalahan saat ini adalah informasi hoax yang telah memecah belah publik. Hal itu diperparah dengan kondisi bahwa sejumlah media massa sudah berpihak kepada salah satu pihak sehingga kepercayaan masyarakat pada media mainstream sudah luntur. Masyarakat harus menyelidiki benar atau tidak informasi yang akan dibagikannya (cek sumber). Salah satu upaya untuk menangkal berita hoax adalah memberikan pengetahuan dan pemahaman tentang bahaya berita hoax dan penangkalannya kepada perkumpulan ibu-ibu PKK sebagai bentuk kepedulian sosial. Pengetahuan yang diberikan kepada ibu-ibu adalah tentang bahaya berita hoax, dampak berita hoax, dan penangkalan berita hoax. Metode yang digunakan dalam kegiatan pengabdian ini adalah ceramah dan tanya jawab, yaitu penyampaian materi tentang arti hoax, ciri informasi hoax, jenis informasi hoax, contoh berita hoax, cara cerdas menangkal berita hoax, dan mengikutsertakan dalam grup diskusi anti hoax. Selain ceramah juga dilakukan diskusi dan tanya jawab untuk memberikan kesempatan kepada peserta dalam memahami lebih lanjut tentang materi yang disampaikan. Hasil dari kegiatan ini ibu-ibu PKK khususnya di kelurahan Karang Besuki RT $11 \mathrm{RW} 3$ Kecamatan Sukun Kota Malang adalah meningkatnya wawasan penangkalan berita hoax dan mampu menjadi solusi dalam menangkal berita hoax melalui media sosial.
\end{abstract}

Kata Kunci: berita hoax, ibu-ibu, PKK, penangkalan

\section{PENDAHULUAN}

Permasalahan yang terjadi saat ini adalah banyaknya informasi hoax yang telah memecah belah publik. Kondisi tersebut diperparah dengan adanya akun media sosial online yang ikut berperan dalam menyebarkan berita hoax. Penyebaran informasi hoax menimbulkan keresahan. Untuk itu masyarakat perlu diingatkan agar mampu memanfaatkan media sosial secara positif dan jangan mudah termakan isu tidak benar. Masyarakat harus menyelidiki benar atau tidak informasi yang akan dibagikannya (cek sumber). Jika tidak benar, memuat fitnah, hingga anjuran kekerasan, maka informasi itu tidak perlu disebarkan.

Menyebarnya berita hoax di media sosial manapun jika penggunanya atau yang mendapat informasinya tidak membaca berita tersebut secara bijak, maka bisa dipastikan dia akan selamanya terjebak arus berita hoax. Tidak hanya itu, mereka yang tidak bijak dalam membaca beritapun akan ikut membuat hoax tandingan sehingga antara kelompok satu dengan yang lainnya tidak akan pernah habis untuk saling serang di media sosial. Sudah bisa dipastikan, orang atau kelompok tersebut sudah memiliki perspektif pemikiran yang salah dan hanya bisa saling menyalahkan tanpa menyeimbangkan pemikiran mereka. Sanksi bagi penyebar informasi hoax bisa dikenakan hukuman sesuai yang tercantum dalam Undang-Undang Nomor 11 Tahun 2008 tentang Informasi dan Transaksi Elektronik (UU ITE). Majelis Ulama Indonesia mengeluarkan fatwa tentang bermuamalah di media sosial, yaitu Fatwa Majelis Ulama Indonesia Nomor 24 Tahun 2017 Tentang Hukum dan Pedoman Bermuamalah.

Kondisi masyarakat Indonesia saat ini umumnya senang berbagi informasi. Diikuti dengan perkembangan teknologi digital yang sudah masuk hingga ke berbagai kalangan, mengakibatkan peredaran informasi menjadi kian sulit terbendung. Menteri Komunikasi dan Informatika Rudiantara menyebutkan, sedikitnya 170 juta masyarakat Indonesia memiliki minimal satu ponsel atau setidaknya satu SIM card. Dengan demikian, mereka bisa berbagi informasi dengan cepat. Media sosial dan aplikasi pengirim pesat cepat (chat apps) menjadi media favorit. Namun, rupanya hal ini menimbulkan suatu polemik baru. Informasi benar dan salah menjadi campur aduk [1]. 
Interaksi di media sosial, adalah hal yang tak bisa dicegah dan dibendung. Pembatasan dalam penggunaan media sosial sama saja dengan membatasi masuknya hal-hal positif. Sebab, media sosial di sisi lain juga membawa banyak dampak positif. Contohnya bagi ibu-ibu yang suka memasak dapat membagikan foto hasil masakannya, berbagai tips memasak, bahkan bisa menjadi lahan penghasilan dengan berjualan di Facebook, instagram dan berbagai media sosial lainnya. Masih banyak yang bisa dimanfaatkan untuk hal-hal positif. Pada era saat masyarakat sulit membedakan informasi yang benar dan salah, hal terpenting adalah meningkatkan literasi media dan literasi media sosial. Sebab, penyebaran informasi hoax juga dapat dilakukan oleh mereka yang terpelajar. Pengguna smartphone ketika membaca berita lewat Twitter, Facebook, WhatsApp, hanya melihat judul saja kemudian disebarkan. Hal ini merupakan fakta, karakter yang menarik dan tidak pernah terjadi sebelumnya. Selain kebiasaan berbagi secara cepat, pola baca masyarakat juga berubah total. Jika sebelumnya membaca buku ditandai dengan halaman dan koran dengan penanda alinea, pembaca berita online cenderung membaca secara cepat. Hal itu didukung dengan format berita dalam jaringan. Portal berita yang paling banyak dibaca adalah yang hanya terdiri dari beberapa alinea, bahkan penyajiannya cenderung tidak lengkap dalam satu berita.

Salah satu upaya untuk menangkal berita hoax adalah dengan memberikan pengetahuan dan pemahaman tentang bahaya berita hoax dan penangkalannya kepada perkumpulan ibu-ibu PKK sebagai bentuk kepedulian sosial. Pengetahuan yang diberikan adalah tentang bahaya berita hoax, dampak berita hoax, dan penangkalan berita hoax. Hal ini yang dilakukan oleh Politeknik Negeri Malang kepada perkumpulan ibu-ibu PKK di kelurahan Karang Besuki RT 11 RW 3 Kecamatan Sukun Kabupaten Malang. Hasil dari kegiatan ini diharapkan mampu menjadi solusi permasalahan melalui peningkatan wawasan dan pemahaman ibuibu PKK agar memiliki kematangan berfikir dalam menangkal berita hoax melalui media sosial.

\section{METODE}

\subsection{Metode Pelaksanaan PPM}

Langkah-langkah yang telah dilakukan dalam pelaksanaan pengabdian pada masyarakat ini adalah sebagai berikut :
1. Memberikan pelatihan tentang motivasi kesadaran hukum dan kematangan berfikir.

2. Pelaksanaan pelatihan dilakukan dengan metode ceramah dan tanya jawab oleh mentor yang berpengalaman.

3. Mambantu menyelesaikan permasalahan dalam bentuk konsultasi dan memberikan pendampingan.

4. Pendampingan dalam bentuk konseling.

5. Evaluasi dan monitoring hasil kegiatan.

Metode yang digunakan dalam kegiatan PPM ini adalah tatap muka dengan cara:

a. Ceramah

Materi tentang penangkalan berita hoax diberikan dengan metode ceramah, yaitu penyampaian materi yang sesuai dengan bimbingan yang dilaksanakan serta dengan memberikan materi yang ada di slide ppt.
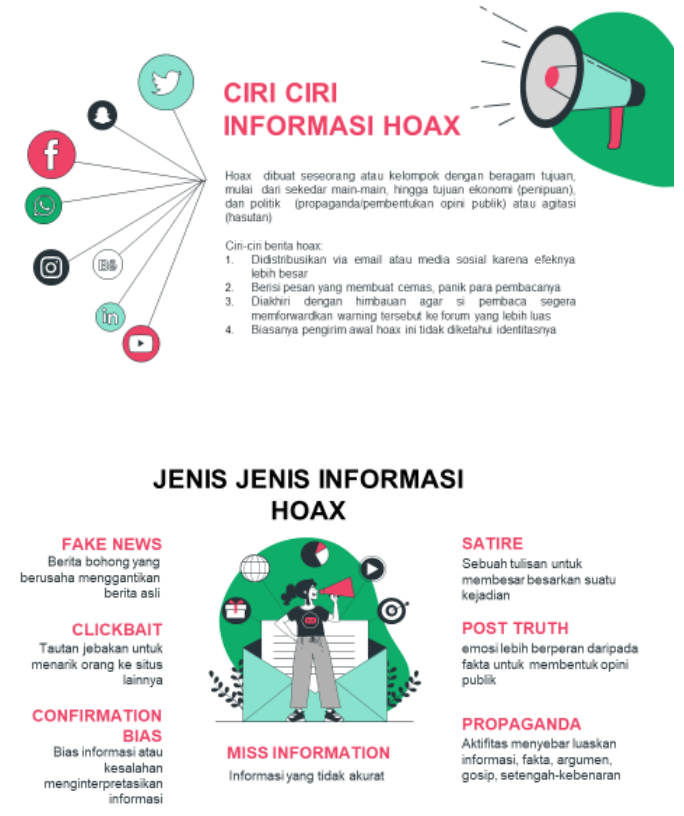

Gambar 1 Materi ceramah

\section{b. Diskusi dan Tanya Jawab}

Diskusi dan tanya jawab dilaksanakan untuk memberikan ruang kepada khalayak sasaran yaitu Ibu-Ibu PKK RT 11 RW Kelurahan Karang Besuki dalam memahami lebih lanjut tentang materi yang disampaikan serta membantu membangun hubungan yang lebih erat antara pelaksana PPM dan khalayak sasaran. 


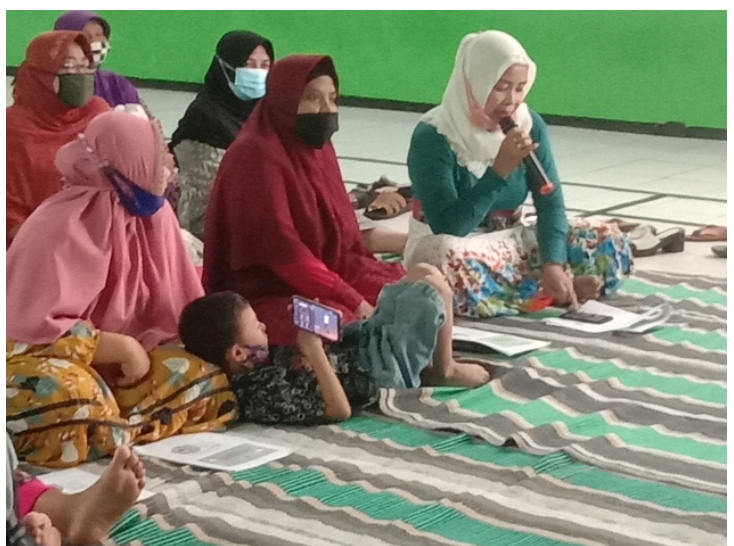

Gambar 2 Keaktifan peserta dalam mengikuti kegiatan diskusi

\section{HASIL DAN PEMBAHASAN}

\subsection{Pengertian Hoax}

Hoax dalam kata Bahasa Inggris artinya tipuan, menipu, berita bohong, berita palsu atau kabar burung. Berita bohong adalah berita yang isinya tidak sesuai dengan kebenaran yang sesungguhnya/ materiële waarheid [2]. Hoax bukan singkatan tetapi satu kata dalam bahasa inggris yang punya arti sendiri. Sedangkan definisi Hoax menurut wikipedia adalah: "Sebuah pemberitaan palsu adalah usaha untuk menipu atau mengakali pembaca/ pendengarnya untuk mempercayai sesuatu, padahal sang pencipta berita palsu tersebut tahu bahwa berita tersebut tidak benar. Salah satu contoh pemberitaan palsu yang paling umum adalah mengklaim sesuatu barang atau kejadian dengan suatu sebutan yang berbeda dengan barang/ kejadian sejatinya. Suatu pemberitaan palsu berbeda denganmisalnya pertunjukan sulap dalam pemberitaan palsu, pendengar/ penonton tidak sadar sedang dibohongi, sedangkan pada suatu pertunjukan sulap, penonton justru mengharapkan supaya ditipu [3].

Jenis-jenis Informasi [4] : 1) Fake news: Berita bohong: Berita yang berusaha menggantikan berita yang asli. Berita ini bertujuan untuk memalsukan atau memasukkan ketidakbenaran dalam suatu berita. Penulis berita bohong biasanya menambahkan hal-hal yang tidak benar dan teori persengkokolan, makin aneh, makin baik. Berita bohong bukanlah komentar humor terhadap suatu berita; 2) Clickbait: Tautan jebakan: Tautan yang diletakkan secara stategis di dalam suatu situs dengan tujuan untuk menarik orang masuk ke situs lainnya. Konten di dalam tautan ini sesuai fakta namun judulnya dibuat berlebihan atau dipasang gambar yang menarik untuk memancing pembaca; 3) Bias konfirmasi: Kecenderungan untuk menginterpretasikan kejadian yang baru terjadi sebagai bukti dari kepercayaan yang sudah ada; 4) Misinformation: Informasi yang salah atau tidak akurat, terutama yang ditujukan untuk menipu; 5) Satire: Sebuah tulisan yang menggunakan humor, ironi, hal yang dibesar-besarkan untuk mengkomentari kejadian yang sedang hangat. Berita satir dapat dijumpai di pertunjukan televisi seperti "Saturday Night Live" dan "This Hour has 22 Minutes"; 6) Post-truth atau Pasca-kebenaran: Kejadian di mana emosi lebih berperan daripada fakta untuk membentuk opini publik, dan 7) Propaganda: Aktifitas menyebarluaskan informasi, fakta, argumen, gosip, setengah kebenaran, atau bahkan kebohongan untuk mempengaruhi opini publik.

Adapun beberapa jenis Hoax yang berkembang saat ini, seperti berikut :1) Hoax Virus: Hoax jenis ini biasanya dikembangkan oleh hacker dan melakukan penyebarannya lewat email atau aplikasi chatting. Hoax jenis ini biasanya berisi tentang adanya virus berbahaya di komputer atau smartphone Anda yang sebenarnya tidak terinfeksi; 2) Hoax Kirim Pesan Berantai: Pengguna aktif aplikasi chatting WhatsApp, pasti sering mendapat pesan untuk melanjutkan pesan ke beberapa teman lain dengan berbagai alasan. Biasanya, pesan tersebut tentang mendapat hadiah tertentu atau mengalami hal buruk jika tidak mengirimkannya; 3) Hoax Urban Legend: Banyak orang yang suka membuat hoax soal cerita urban legend seram tentang tempat, benda, atau kegiatan tertentu. Hoax jenis ini biasanya menghimbau netizen untuk tidak mengunjungi, membeli, atau melakukan hal yang telah disebutkan pembuat hoax tadi. Hoax jenis ini dapat berimbas negatif pada si objek kabar hoax, seperti mulai dijauhi sampai nilai ekonomisnya menurun. Sekilas hoax ini mirip dengan black campaign; 4) Hoax mendapat Hadiah Gratis: Hoax satu ini modusnya mirip dengan penipuan online. Oknum akan mengirimkan pesan broadcast atau pop-up message berisikan pengumuman pemberian hadiah gratis. Di sini, memang korban jarang ada yang mengalami kerugian uang, namun mereka tertipu dengan mengisi survei-survei internet untuk iklan. Dampak negatif akan semakin besar apabila si korban tidak sengaja menggunakan email kantor atau email utama untuk mendaftarkan diri di survei tersebut. Jika terjadi, maka email-email iklan dipastikan mengalir deras dan susah untuk dihentikan; 5) Hoax tentang Kisah Menyedihkan: Hoax satu ini berupa surat yang berisikan tentang kabar dari seseorang yang tengah sakit dan membutuhkan dana guna operasi atau obat. 
Hoax jenis ini biasanya menggunakan foto dari Google demi mendapatkan simpati. Oknum dari penyebar hoax ini turut menyertakan nomor rekening agar korban yang tertipu bisa mengirimkan beberapa jumlah uang, dan 6) Hoax Pencemaran Nama: Sifat hoax ini sangat berbahaya. Karena dari berita palsu bisa dengan mudah tersebar di dunia maya dan mampu menghancurkan hidup seseorang dalam sekejab. Media sosial sendiri didefinisikan sebagai media online, dengan para penggunanya bisa dengan mudah berpartisipasi, berbagi, dan menciptakan isi meliputi blog, jejaring sosial, wiki, forum dan dunia virtual. Blog, jejaring sosial dan wiki merupakan bentuk media sosial yang paling umum digunakan oleh masyarakat di seluruh dunia. Sumber lain mendefinisikan bahwa media sosial adalah sebuah struktur sosial yang dibentuk dari simpul-simpul yang dijalin dengan satu atau lebih tipe relasi spesifik. Jejaring sosial atau media sosial bisa diartikan sebagai sarana pemersatu antara individu satu dengan individu yang lain sehingga menjadi sebuah sosial yang saling berkaitan (berinteraksi) satu sama lain [5].

\subsection{Pengertian Media Sosial}

Media sosial tidak jauh berbeda dengan media siber (cyber) dikarenakan media sosial merupakan salah satu platform dari media siber. Namun demikian media sosial memiliki karakter khusus, yaitu : 1) Jaringan (Network), jaringan adalah infrastruktur yang menghubungkan antara komputer dengan perangkat keras lainnya. Koneksi ini diperlukan karena komunikasi bisa terjadi jika antar komputer terhubung, termasuk di dalamnya perpindahan data; 2) Informasi (Information), Informasi menjadi entitas penting di media sosial karena pengguna media sosial mengkreasikan representasi identitasnya, memproduksi konten, dan melakukan interaksi berdasarkan informasi; 3) Arsip (Archive), Bagi pengguna media sosial, arsip menjadi sebuah karakter yang menjelaskan bahwa informasi telah tersimpan dan bisa diakses kapanpun dan melalui perangkat apapun; 4) Interaksi (Interactivity) Media sosial membentuk jaringan antar pengguna yang tidak sekedar memperluas hubungan pertemanan atau pengikut (follower) semata, tetapi harus dibangun dengan interaksi antar pengguna tersebut; 5) Simulasi Sosial (simulation of society) Media sosial memiliki karakter sebagai media berlangsungnya masyarakat (society) di dunia virtual. Media sosial memiliki keunikan dan pola yang dalam banyak kasus berbeda dan tidak dijumpai dalam tatanan masyarakat yang real, dan 6) Konten oleh pengguna UGC (Use-generated content) : konten buatan pengguna yang dipublikasikan dalam sebuah sistem. Di media sosial konten sepenuhnya milik dan berdasarkan kontribusi pengguna atau pemilik akun. UGC merupakan relasi simbiosis dalam budaya media baru yang memberikan kesempatan dan keleluasaan pengguna untuk berpartisipasi. Hal ini berbeda dengan media lama (tradisional) dimana khalayak sebatas menjadi objek atau sasaran yang pasif dalam distribusi pesan [6].

\subsection{Pembahasan Masalah}

Dalam kegiatan ini pelaksana PPM dan Bapak Ketua RT 11 RW 3 Kelurahan Karang Besuki terlibat secara langsung membantu para peserta ibu-ibu PKK dalam memahami materi dengan benar, memilih kata sesuai dengan bahasa Indonesia yang sesuai dengan ejaan yang disempurnakan, menjaga situasi tetap serius tapi santai, dengan menggunakan bahasa yang tegas, lugas tapi sopan, terutama bagaimana memberikan informasi dan memberi contoh tanpa menggurui.

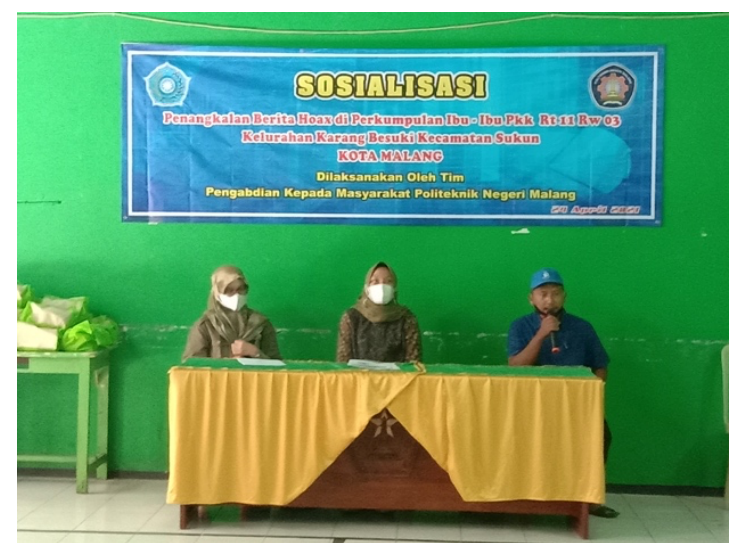

Gambar 3 Pelaksanaan PPM diskusi dan tanya jawab

\subsection{Rancangan Evaluasi}

Rancangan evaluasi yang akan digunakan dalam pelaksanaan pengabdian kepada masyarakat ini adalah dengan menganalisis faktor pendukung dan faktor penghambat sehingga akan didapatkan suatu metode yang tepat untuk melaksanakan pelatihan. Hal-hal lainnya yang akan dievaluasi dalam pengabdian kepada masyarakat ini adalah efektifitas, ketepatan, dan kegunaan pelatihan dalam membangun motivasi kematangan berfikir dan kesadaran bahaya berita hoax sehingga dapat mengantisipasi dampak negatif dari berita hoax.

\section{1. . Evaluasi Sebelum Kegiatan}

Melaksanakan observasi pendahuluan dengan mengajukan kerjasama kepada Bapak Ketua RT 11 RW 3 Kelurahan Karang Besuki, membuat 
persiapan materi dan media, agar kedua hal yang telah dirancang bisa diterima oleh peserta, dan mencari lokasi yang terbuka dan longgar untuk menjaga jarak antar peserta.

\section{Evaluasi Selama Kegiatan}

Selama melakukan kegiatan, dilakukan evaluasi sebagai berikut:

a. Evaluasi terhadap kehadiran peserta dan kesiapan tempat serta ketersediaan bahanbahan ajar, fasilitas dan tata ruang.

b. Evaluasi hambatan baik masalah penyampaian materi maupun hal-hal yang bersifat teknis.

c. Evaluasi kelayakan materi yang diberikan.

d. Evaluasi daya penerimaan materi peserta/ penyerapan materi.

e. Evaluasi terhadap reaksi para peserta.

\section{Evaluasi akhir kegiatan}

\subsection{Hasil Kegiatan PPM}

Kegiatan PPM ini dilaksanakan dalam bentuk pemberian wawasan kepada peserta melalui metode ceramah dan diskusi tanya jawab antara pelaksana PPM dan ibu-ibu PKK RT 11 RW 3 Kelurahan Karang Besuki Kecamatan Sukun Malang. Kegiatan dilaksanakan pada Hari Sabtu, tanggal 24 April 2021 jam 09.00- 10.30 WIB, bertempat di gedung Balai RW 03 Kelurahan Karang Besuki (ex Balai Desa Karang Besuki) dan dihadiri oleh Bapak Ketua RT 11 RW 3 Kelurahan Karang Besuki, Ketua PKK RT 11 RW 3, Ketua Koperasi RT 11 RW 3, dan perwakilan dari ibu-ibu PKK RT 11 RW 3 Kelurahan Karang Besuki.

adalah :

Adapun tujuan dari kegiatan pengabdian ini

1. Meningkatkan kualitas kematangan berfikir ibuibu terhadap berita hoax.

2. Membangun kesadaran hukum dan pemahaman ibu-ibu terhadap bahaya berita hoax yang beredar di dunia maya.

3. Meningkatkan peran serta ibu-ibu terhadap keluarga dan masyarakat dilingkungan sekitarnya agar bisa membagikan pengetahuan yang didapatkan dalam menggunakan telepon genggam pintar (smartphone) secara bijak untuk menangkal berita hoax.

Tercapainya tujuan dari Pengabdian Pada Masyarakat ini memang belum terlihat langsung. Namun dengan melihat semangat ibu-ibu dalam mengikuti kegiatan, diyakini bahwa proses keberhasilan akan didapatkan secara bertahap.
Pada umumnya, pelaksanaan kegiatan ini tidak menemui hambatan yang berarti mengingat materi yang diberikan sangat menarik dan dibutuhkan. Adapun faktor pendorong dari kelancaran kegiatan ini adalah:

- Minat dan semangat para peserta dalam mengikuti kegiatan meski di tengah suasana pandemi, ibu-ibu tetap semangat untuk hadir dan mengikuti kegiatan hingga selesai dengan tetap menerapkan protokol kesehatan.

- Aparat setempat, dalam hal ini pimpinan RW dan pimpinan RT sangat mendukung kegiatan ini dengan memberi izin serta menyediakan tempat dan peralatan pendukung.

Untuk mengetahui hasil dari pelaksanaan PPM, kami menyebarkan kuesioner kepada mitra yaitu ibu-ibu PKK RT 11 RW 3 Kelurahan Karang Besuki. Indikator dalam kuesioner meliputi solusi atas masalah yang dihadapi mitra, keaktifan anggota tim PPM, kesesuaian pendampingan oleh anggota tim PPM, peningkatan kemandirian atau pengetahuan dan ketrampilan ibu-ibu PKK, dan kepuasan ibu-ibu PKK atas pelaksanaan sosialisasi penangkalan berita hoax. Hasil dari kuesioner tersusun dalam Tabel 1.

Tabel 1 hasil kuesioner kepuasan mitra

\begin{tabular}{|c|l|l|}
\hline No. & \multicolumn{1}{|c|}{ Indikator } & \multicolumn{1}{|c|}{ Hasil } \\
\hline 1. & $\begin{array}{l}\text { Pemberian solusi atas masalah } \\
\text { yang dihadapi mitra }\end{array}$ & $\begin{array}{l}\text { Sangat baik }: 16 \\
\text { Baik }: 9 \\
\text { Tidak baik }: 0\end{array}$ \\
\hline 2. & Keaktifan anggota tim PPM & $\begin{array}{l}\text { Sangat baik }: 17 \\
\text { Baik }: 8 \\
\text { Tidak baik }: 0\end{array}$ \\
\hline 3. & $\begin{array}{l}\text { Kesesuaian pendampingan } \\
\text { oleh anggota tim PPM }\end{array}$ & $\begin{array}{l}\text { Sangat baik }: 18 \\
\text { Baik }: 7 \\
\text { Tidak baik }: 0\end{array}$ \\
\hline 4. & $\begin{array}{l}\text { Peningkatan kemandirian atau } \\
\text { pengetahuan dan ketrampilan } \\
\text { ibu-ibu PKK }\end{array}$ & $\begin{array}{l}\text { Sangat baik }: 16 \\
\text { Baik } \\
\text { Tidak baik }: 0\end{array}$ \\
\hline 5. & $\begin{array}{l}\text { Kepuasan ibu-ibu PKK atas } \\
\text { pelaksanaan sosialisasi } \\
\text { penangkalan berita hoax. }\end{array}$ & $\begin{array}{l}\text { Sangat baik }: 24 \\
\text { Baik } \\
\text { Tidak baik }: 0\end{array}$ \\
\hline
\end{tabular}

Dari hasil kuesioner menunjukkan bahwa kegiatan PPM sudah berjalan dengan baik dan kontribusi dari mitra ibu-ibu anggota PKK RT 11 RW 3 Kelurahan Karang Besuki Kecamatan Sukun Kota Malang adalah dengan memberikan masukan agar setiap tahun diadakan kegiatan PPM. Kemudian adanya penyaringan informasi dalam kelompokkelompok komunikasi dalam aplikasi whatsapp sehingga akan lebih berhati-hati dalam memberikan informasi melalui aplikasi tersebut. Kegiatan PPM 
dipublikasikan dalam media massa Radar Malang dalam versi cetak, yaitu pada tanggal 28 April 2021.

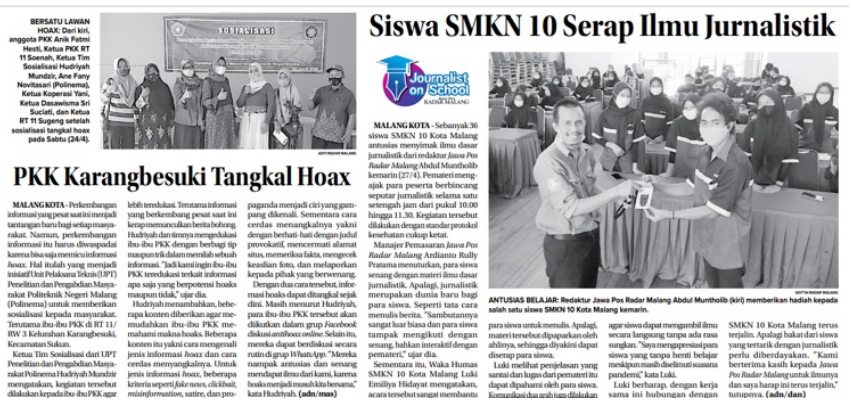

Gambar 4 Publikasi kegiatan PPM pada media massa Radar Malang 28 April 2021

\section{KESIMPULAN}

Beberapa kesimpulan yang dapat diambil pada kegiatan Pengabdian Kepada Masyarakat adalah:

1. Peserta pelatihan kegiatan PPM ini adalah Ibu-ibu Anggota PKK RT 11 RW 3 Kelurahan Karang Besuki Kecamatan Sukun Kota Malang.

2. Peserta sangat antusias dalam mengikuti kegiatan pelatihan. Hal ini ditunjukkan dengan banyaknya pertanyaan dan respon menjawab ketika diberi pertanyaan.

3. Keberhasilan dari kegiatan pengabdian ini memang belum dapat dilihat secara langsung dan keseluruhan. Namun jika dilihat dari hasil yang dicapai dan hasil kuesioner, maka manfaat yang didapatkan adalah dengan bertambahnya wawasan dan pengetahuan dalam menangkal berita hoax, serta membangun kesadaran hukum dan pemahaman ibu-ibu terhadap bahaya berita hoax yang beredar di dunia maya.

\section{SARAN}

Saran yang disampaikan antara lain :

1. Kegiatan PPM hendaknya dilaksanakan secara berkelanjutan agar pemahaman masyarakat khususnya ibu-ibu PKK RT 11 RW 3 Kelurahan Karang Besuki Kecamatan Sukun Kota Malang tentang penangkalan berita hoax semakin meningkat.

2. Hendaknya ibu-ibu anggota PKK RT 11 RW 3 Kelurahan Karang Besuki Kecamatan Sukun Kota Malang dapat menerapkan kepribadian yang sadar dan paham hukum menggunakan media sosial dalam kehidupan sehari-hari, mudah beradaptasi dengan perkembangan teknologi dan dapat mengajarkan serta memberi teladan yang baik kepada putra putrinya.

3. Kegiatan PPM perlu direncanakan secara terprogram dan simultan sehingga masingmasing perguruan tinggi termasuk POLINEMA dapat memberikan pendampingan penanaman kesadaran dan pemahaman tentang hukum dalam penangkalan berita hoax.

\section{UCAPAN TERIMA KASIH}

Kami mengucapkan terima kasih kepada Politeknik Negeri Malang yang telah memberikan dukungan moral dan dana terhadap Program Pengabdian Kepada Masyarakat, dengan Dana DIPA Politeknik Negeri Malang, Nomor: SP DIPA 023.18.2.677606/2021.

\section{DAFTAR PUSTAKA}

[1] https://kominfo.go.id/content/detail/35530/ siaran -pers-no239hmkominfo072021-tentang-cegahperedaran-kartu-sim-ilegal-kominfo-larangpenjualan-dalam-keadaan-aktif/0/siaran pers.

[2] Chazawi, A., Ferdian, A., 2016, Tindak Pidana Pemalsuan, PT Rajagrafindo Persada, Jakarta.

[3]Berita bohong : wikipedia, https://www.google. com/search?client=firefox-b-d\&q=arti + hoax + wikipedia.

[4] Rahadi, D. R., 2017, Perilaku Penggunaan dan Informasi Hoax di Media Sosial, Jurnal Manajemen \& kewirausahaan No. 1, JMDK, Vol. 5, hal.62.

[5] Putra, E. D., 2014, Menguak Jejaring Sosial, PT Rajagrafindo Persada, Depok.

[6] Nasrullah, R., 2015, Media Sosial: Perspektif Komunikasi, Budaya, dan Sosioteknologi, Simbiosa Rekatama Media, Bandung. 